University of South Carolina

Scholar Commons

10-1995

\title{
An Historical Critique of the Emergence and Evolution of Ernesto Che Guevara's Foco Theory
}

Matt D. Childs

University of South Carolina - Columbia, childsmd@mailbox.sc.edu

Follow this and additional works at: https://scholarcommons.sc.edu/hist_facpub

Part of the History Commons

\section{Publication Info}

Published in Journal of Latin American Studies, ed. Gareth A. Jones, Rory Miller, Fiona Macaulay, Volume 27, Issue 3, 1995, pages 593-624.

Childs, M. D. (1995). An historical critique of the emergence and evolution of Ernesto Che Guevara's foco theory. Journal of Latin American Studies, 27(3), 593-624.

(c) Journal of Latin American Studies, 1995, Cambridge University Press

http://journals.cambridge.org/action/displayJournal?jid=LAS

This Article is brought to you by the History, Department of at Scholar Commons. It has been accepted for inclusion in Faculty Publications by an authorized administrator of Scholar Commons. For more information, please contact digres@mailbox.sc.edu. 


\title{
An Historical Critique of the Emergence and Evolution of Ernesto Che Guevara's Foco Theory*
}

\author{
MATT D. CHILDS
}

Abstract. This article provides an analysis of Ernesto Che Guevara's theory of guerrilla warfare, the foco. The numerous changes to the original foco thesis, as presented in Guerrilla Warfare (1960), are examined in detail covering two dozen articles, speeches, essays, interviews and books authored by Guevara, Castro and Debray while stressing their relation to national and international politics. The author argues that there was an apparent discourse between Cuban politics and the numerous changes in Guevara's writings. Juxtaposing changes to the foco theory from 1960 to 1967 , to Cuban historical events, reflects the political expedience of the 1960 s and the primary interests of the fidelistas, specifically Guevara.

Scholarly analysis of the Cuban Revolution, both inside and outside Cuba, describes the role the sierra (guerrillas) and llano (urban underground) played in the overthrow of Batista. Maurice Halperin, in his recently published memoirs, points out the uneven focus in Cuban historiography on the sierra's role in the Revolution: 'Although the underground played a crucial role in the triumph of Castro's guerrilla forces, the full story has never been told to this day.' According to Halperin, 'Castro discouraged ... publicity concerning the underground exploits [because] it could diminish the exclusive role he wished to attribute to his guerrilla troops... in the overthrow of Batista's government., ${ }^{2}$ As a result, the

* The author would like to thank Ernest Boyd, Edward González, Juan Moreno, and Roberto Oregel, in addition to the anonymous JLAS referees, for their helpful comments and suggestions; however, the author is solely responsible for the content of the article and any errors or oversights.

1 Halperin taught at the University of Havana and served as an economic advisor in Cuba between 1962 and 1968 where he worked closely with many high officials of the regime, including Ernesto Che Guevara. The quote is taken from an early publication of his memoirs which appeared as 'Return to Havana: Portrait of a Loyalist', in Cuban Studies/Estudios Cubanos, vol. 23 (1993), pp. 187-93.

${ }^{2}$ Ibid., p. 188. Halperin is certainly not the first to make this observation. The historiography of the Cuban Revolution as commented on by Andrés Suárez, 'The Cuban Revolution: The Road to Power', Latin American Research Review, vol. 7, no. 3 (Fall, 1972), pp. 5-29, notes the paucity of material on the llano's contribution to the

Matt D. Childs is a doctoral student at the University of Texas at Austin. 
history of the Cuban Revolution, especially in the I960s, by elevating and focusing on the role of Castro and his supporters, while neglecting the activities of the urban underground, served to justify and strengthen the fidelistas' centrality in the Cuban political apparatus.

The selective emphasis and representation of the Cuban Revolution by veterans of the Sierra Maestra is apparent not only in the historiography, ${ }^{3}$ but numerous other areas such as politics, culture, economics, and society. In this article I will focus specifically on the corpus of writings on guerrilla warfare produced in Havana following the Revolution, with special attention given to how the ahistorical representation of the sierra affected the emergence and evolution of Ernesto $\mathrm{Che}^{4}$ Guevara's guerrilla warfare theory, the foco. ${ }^{5} \mathrm{I}$ will argue that there existed an implicit-and sometimes an explicit-discourse between national and international politics and formulation of the foco theory. The gradual, yet noticeable, evolution of the foco theory from 1960 to 1967 reflects a fundamental distortion of the Cuban guerrilla experience, reveals the primary interests

Batista struggle. Fidel Castro himself later acknowledged the sierra biass in 1968: '[A]lmost all attention, almost all recognition, almost all the admiration and almost all the history of the Revolution has centred on the guerrilla movement in the mountains. And this fact tended to play down the role of those who fought in the clandestine movement, and the extraordinary herosim of young persons who died fighting under very difficult conditions.' Quoted in Edward González, Cuba Under Castro: The Limits of Charisma (Boston, 1974), pp. 9 $\mathrm{I}^{-2}$. Three works, among others, which adequately address the role of the llano in the revolutionary war are Ramón L. Bonachea and Marta San Martín, The Cuba Insurrection, 1952-1959 (New Brunswick, New Jersey, 1974); Hugh Thomas, Cuba: The Pursuit of Freedom (New York, 1971); and useful documents on llano activities can be found in the work by one-time regime supporter Carlos Franqui, Diario de la Revolución Cubana (Paris, 1976).

3 For example see Ernesto Che Guevara, Reminiscences of the Cuban Revolutionary War, trans., Victoria Ortiz (New York, 1968).

4 Throughout this essay Che will be written without the accent which numerous authors place over the e. I have chosen not to use the accent because Che himself never employed it nor did Fidel Castro in their correspondence, whether it was linguistically correct or not. Ernesto Guevara officially became El Che 'on 9 January I 959 [when] the council of ministers made Che Guevara a Cuban citizen, and at that time, he legalised Che as part of his name'. Taken from the introduction by John Gerassi to Ernesto Che Guevara, Venceremos! The Speeches and Writings of Che Guevara (New York, 1968), p. I4. Guevara actually became an official citizen of Cuba on 9 February 1959. See 'Che Guevara, 1959-1967: Cronología', Universidad de la Habana (Julio-Dic, 1967), pp. $270-6$.

5 'The foco theory will be elaborated and analysed later. In brief, the 'foco' refers to a small guerrilla band located in the mountains, while the 'foco theory', or 'foquisimo', refers to the primacy given to the rural armed struggle centralised in the sierra with emphasis on subjective conditions. The terminology may be confusing since the 'foco theory' and the 'foco' itself have distinct connotations. Throughout this essay the 'foco theory' will refer to the guerrilla warfare literature authored by Guevara, Debray, and Castro. The 'foco' will represent the insurrectionary force. 
of the fidelistas, most prominently Guevara, and offers insights into the strong divisions within the government as they spilled onto the pages of guerrilla warfare. This point will be demonstrated through a close examination of the 'Escalante Affair' where the foco theory and national and international politics all intertwined. Before delving directly into the foco theory, it is first necessary to address its overall significance and the empirical base from which it emerged, the Cuban Revolution.

\section{The Importance of the Foco Theory}

A critical examination of the foco theory will address several important issues. First, and most obviously, why did the foco theory change? Second, a critical analysis of the foco theory enables a better understanding of Che's Bolivian fiasco whereby it becomes obvious that the strategy and tactics of Bolivia differed from those of the Sierra Maestra. Third, nearly every Latin American guerrilla movement of the 1960s adopted Guevara's theory. And fourth, an examination of how and why the foco theory changed illustrates that it did change from Guerrilla Warfare to Che's death, which many authors do not acknowledge. For example, the respected Mexican political scientist Jorge G. Castañeda in his latest book, Utopia Unarmed: The Latin American Left After the Cold War, cites Che's I 960 tenet that 'where a government has come to power through some form of popular vote, fraudulent or not, and maintains at least an appearance of constitutional legality, the guerrilla outbreak cannot be promoted, since the possibilities of peaceful struggle have not yet been exhausted ${ }^{6}{ }^{6}$ Castañeda then goes on to comment in a footnote that 'it is worth noting that on various occasions and in several countries, the Cubans and Latin guerrillas themselves disregarded Guevara's law'? Castañeda does not recognise that Guevara himself changes his own 'law' in an article published in Cuba Socialista during 1963 in which he dropped the democratic corollary and advocated armed struggle in existing democracies such as Venezuela. ${ }^{8}$

6 Jorge G. Castañeda, Utopian Unarmed: The Latin America Left after the Cold War (New York, 1993), p. 329. For lengthy reviews of Utopia Unarmed see essays by Enrique A. Baloyra, Gustavo Gorriti, and Anthony P. Maingot all in the Journal of Interamerican Studies and World Affairs, vol. 36, no. I (Spring, 1994), pp. I $50-85$; and James Dunkerley, 'Beyond Utopia: The State of the Left in Latin America', New-Left Review, no. 206 (July-Aug., I 994), pp. $27-43$.

7 Castañeda, Utopia Unarmed, p. 329 , fn. 2.

8 The article, which Castañeda was not aware of or did not recognise, is actually well known and will be analysed later; Ernesto Che Guevara, 'Guerra de Guerrillas: Un Método', Cuba Socialista (Sept., I963), pp. I-17. Perhaps even more surprising, Régis Debray, who surely studied the article, was thanked by Castañeda in the preface for reading the manuscript. Castañeda is by no means the first not to take account of the important changes in Guevara's guerrilla thought, and hence the need for such analysis. The well known spokesman for the American 'new-left', I. F. Stone, who knew 
The importance of the foco theory in Cuba's foreign policy throughout the ig6os until Guevara's death cannot be overemphasised. As Jorge I. Domínguez pointed out in his book, To Make a World Safe for Revolution, it became the guiding principle of Cuba's international organisations such as the Organisation of Latin American Solidarity (OLAS) and Tricontinental, both of which sought to combat Cuba's isolation. ${ }^{9}$ The Guevarista line also served as a medium by which Cuban communism stood in clear contradistinction from the Marxism-Leninism of the Soviet Union as it advocated the primacy of subjective conditions, the ability to speed up history, not to mention its mocking attitude of détente. In addition, as Edward González argues, the Cuban Revolution's strong following in Latin America increased the value of Cuba as an ally to the Soviet Union, multiplying the island's worth several fold in Moscow. ${ }^{10}$

The Cuban Revolution caused shock waves that resonated throughout the hemisphere, qualifying 1959 as the watershed date in the history of the armed Latin American left, or as Castañeda appropriately labels the year, the 'Cuban Crucible'. ${ }^{11}$ While it is undoubtedly true that the left's overall following increased as a result of Castro's victory, at the same time it became increasingly sectarian and divided. ${ }^{12}$ Among the Latin American

Guevara personally, made the same comment in an obituary/homage article which appeared in New Statesman (20 October 1967) and reprinted as a 'Prefatory Note' to the 1968 Vintage edition of Guerrilla Warfare. Equabal Ahmad was also unaware of the change when he criticised Debray's Revolution in the Revolution? claiming there is 'no discussion of Che Guevara's contention that guerrilla insurgency cannot succeed against a government which is able to maintain some legitimacy through the pretense of democracy'. Eqabal Ahmad, 'Radical But Wrong', in Leo Huberman and Paul M. Sweezy (eds.), Régis Debray and the Latin American Revolution (New York, I968), p. 73.

9 'Once the revolution had won power at home, Cuba had to attempt to make the world safe for its revolution.... Cuban leaders [sought] to make a world safe for revolution in order to promote and safeguard their values, advance their interests, achieve their ambitions and enhance their influence.' Jorge I. Domínguez, To Make a World Safe for Revolution: Cuba's Foreign Policy (Cambridge, Massachusetts, 1989), pp. 6-7.

10 'Fidelista movements in Latin America not only offered the means by which Cuba could overcome its hemispheric isolation, but also provided Castro either with the means for maintaining and revitalising Soviet interests in Cuba as a revolutionary base, or with a negotiable issue with which he could bargain for major Soviet concessions.' Edward González, 'Relationship with the Soviet Union', in Carmelo Mesa-Lago (ed.), Revolutionary Change in Cuba (Pittsburgh, 1970), p. 87.

11 Castañeda, Utopia Unarmed, pp. 5 I-90.

12 For a discussion of the left in Latin America following the Cuban Revolution, see the following: Richard Gott, Guerrilla Movements in Latin America (Garden City, New York, 1972); the well detailed 'case studies' of guerrilla movements in seven Latin American countries from the 1960 s to the mid 1980 in Che Guevara, Guerrilla Warfare, introduction and case studies by Brian Loveman and Thomas M. Davies Jr. (Lincoln, Nebraska, 1985); Timothy P. Wickham-Crowley, Guerrillas \& Revolution in Latin America: A Comparative Study of Insurgents and Regimes Since 1956 (Princeton, 1992); 
left, the overwhelming issue of division involved the primacy of objective or subjective conditions in the armed struggle. Fidel Castro plainly stated the Cuban position favouring subjective conditions in the famous Second Declaration of Havana, ( 1962 ) declaring: 'The duty of every revolutionary is to make the revolution!' ${ }^{13}$

Unsurprisingly, the foco theory and students of the Cuban Revolution found its strongest following in Nicaragua where Fidel Castro and Che Guevara provided inspiration in an almost religious manner. Tomás Borge described Fidel Castro as 'the resurrection of Sandino, the answer to our reservations, the justification of the dreams of heresy of a few hours before' ${ }^{14}$ The influence of the Cuban Revolution is further reflected in the opening lines of the Sandinista oath: 'Before the images of Augusto César Sandino and Ernesto Che Guevara, before the memory and the heroes and martyrs of Nicaragua, Latin America and all of humanity, before history: I place my hand on the red-and-black banner that signifies Patria Libre 0 Morir! ${ }^{15}$ While it is true that during the early years of the FSLN (1960s) adherence to the foco theory was strictly maintained, it later became an issue of division. Beginning in the mid-1970s three tendencies emerged within the FSLN over what tactics to pursue, specifically challenging the viability of the foco theory in Nicaragua. Today, the continuance of this division within the FSLN remains one of the major obstacles to creating an effective political party. In fact, the present division within the FSLN

Thomas C. Wright, Latin America in the Eera of the Cuban Revolution (New York, 1991); and in particular, William E. Ratliff, Castroism and Communism in Latin America, 1959-1976: The Varieties of the Marxist-Leninist Experience (Stanford, 1976).

13 Despite Castro's commitment to the armed struggle, in 1964 Cuba hosted the Conference of Latin American Communist Parties, giving high priority to various guerrilla movements and agreeing with the Soviet Union on the unfavourability of revolutionary conditions in other countries. Cuban tolerance for several Latin American communist parties unwilling to adopt the armed struggle served to strengthen relations with the Soviet Union. See Ratliff, Castroism and Communism, passim, and Appendix A, pp. $195-9$.

14 Tomás Borge, Carlos, el Almanecer ya no es una Tentación (Managua, 1989), p. 27. See also his work La Paciente Impaciente (Managua, 1989); the autobiographical work by Omar Cabezas, La Montaña es Algo Más Que un Enorme Estepa Verde (Managua, 1982); and Ernesto Cardenal, En Cuba (México, 1977) all provide insight into the importance of the Cuban Revolution from high ranking Sandinistas. Also, works by David Nolan, FSLN: Ideology of the Sandinista and the Nicaraguan Revoluiton (Miami, 1984); and Donald Hodges, Intellectual Foundations of the Nicaraguan Revolution (Austin, 1986) are both essential.

15 Quoted in Stephen Kinzer, The Blood of Brothers: Life and War in Nicaragua (New York, 1991), p. 62. While the importance of the Cuban Revolution to the Sandinistas was immense in providing a model and a theory, one author exaggerates when he describes Che Guevara as 'the single most important icon for revolutionary Nicaraguans'. The author apparently has forgotten the name of the Nicaraguan revolutionaries Sandinistas! Wickham-Crowley, Guerrillas \& Revolution in Latin America, p. 227. 
can trace its origin to the interpretation of the applicability of the foco theory in Nicaragua. ${ }^{\mathbf{1 6}}$

Guevara's theory served Cuban foreign policy. Until his death in 1967 it became the main tool, guiding ideology and providing inspiration for those insurgents who aligned themselves with Cuba. In addition, to the painful realisation of many guerrillas, defeat of the foco theory became the primary obsession of United States foreign policy towards Latin America. Loveman and Davies claim:

[I]n many respects, it may be said that the last quarter century of United States foreign policy toward Latin America has consisted essentially of defeating the threat, the legacy, the legend of Ernesto 'Che' Guevara - the most important martyr of revolutionary struggle in Latin America in the twentieth century, ${ }^{17}$

Che Guevara's writings on guerrilla warfare found a receptive audience not only in Latin America, but throughout the world. In the United States, during the ig6os, several groups went beyond simply quoting Che Guevara, as Stokely Carmichael often did, and put his theory into practice. The 'Weathermen' during their 'Days of Rage' in Chicago legitimised their actions through Guevara's doctrine of dividing United States forces through the creation of 'one, two, three... many Vietnams'. Further, the Black Panthers operated a guerrilla training centre in Cuba, and, as leader Eldrige Cleaver commented, seriously considered adopting the foco theory: 'Trained and equipped forces would be dropped into the mountain areas of North America. The plan here was to have small mobile units that could shift easily in and out of rural areas, living off the land, and tying up thousands of troops in fruitless pursuit.' ${ }^{18}$

The analysis in this article of the emergence and evolution of the foco theory will follow a rather simple method: the primary writings of Guevara, Régis Debray, and to a lesser extent Fidel Castro will be examined as they appeared chronologically, while placing them in their proper historical and political context. ${ }^{19}$ In all, over two dozen documents

16 The emergence of this division during the 1970s is clearly detailed in Nolan's work. The persistence of the division and the obstacles they currently present is tightly analysed by Andrés Pérez, 'The FSLN After the Debacle: The Struggle for the Definition of Sandinismo', Journal of Interamerican Studies and World Affairs, vol. 34, no. I (Spring, 1992), pp. I I I -39 .

17 Brian Loveman and Thomas P. Davies Jr., 'Preface' to Che Guevara, Guerrilla Warfare (Lincoln, Nebraska, 1985), p. ix.

18 Eldridge Cleaver, Soul on Fire (Waco, Texas, 1978), p. 108. He further commented that there 'was much excitement over the possibilities of building of units, surrounded by acres of revolutionary camps and personnel, all working rigorously'. He also added, to emphasise its perceived importance at the time, 'I do not mean to be sarcastic; but in retrospect the grand design seems pretty ridiculous'.

19 A two volume edition entitled Obras Completas, 1957-1967 (Havana, 1970) contains almost all of Guevara's important works on guerrilla warfare. Most of Guevara's writings have been translated into English. The best source for reliability in translation, 
will be surveyed to permit a thorough critique. Analysis will be enhanced by various studies, most of them introductions to Guevara's and Debray's writing, which address the foco theory. Unfortunately, Guevara's works have not been subjected to scholarly criticism, most with commentary simply referring to his unorthodox Marxism. Debray, on the other hand, has been highly scrutinised and blamed for most of the flaws of the foco theory. ${ }^{20}$ Apparently, Debray was easier to criticise, since an attack on the apostle of armed struggle would have jeopardised Havana's support. Indeed, according to Domínguez: 'Cuba expects to be recognized as the leader of international revolutionaries because it believes it has the correct strategy for victory ... [I]t does not support revolutionary movements that do not defer to Cuba.' ${ }^{21}$

Because of the need for brevity in this article, I will treat Guevara's, Debray's, and Castro's writings as one unit. Although different tendencies

completeness, and introduction is Che: Selected Works of Ernesto Guevara, edited by Rolando E. Bonachea and Nelson P. Valdés (Cambridge, Massachusetts, 1969). Several works not found in the Bonachea and Valdés edition are in Gerassi's Venceremos!. Che's book length works such as Guerra de Guerrillas, Pasajes de la Guerra Revolucionaria, and Diario del Che en Bolivia have all been translated into English and gone through numerous editions. Debray's important essays are found in Régis Debray, Strategy for Revolution, edited with an introduction by Robin Blackburn (New York, 1971). His well known lengthy essay has been published in book form, Revolution in the Revolution?, with an introduction by Leo Huberman and Paul M Sweezy, (New York, I 967). Debray's writings following his release from prison such as the Chilean Revolution: Conversations with Allende (New York, 1971); Che's Guerrilla War (Harmondsworth, 1975); and Critique of Arms (New York, 1977) will not be examined in detail. Only those works by Fidel Castro which clearly deal with guerrilla warfare such as the Second Declaration of Havana will be addressed. The political context is covered in the following: Theodore Draper, Castroism: Theory and Practice (New York, 1965); Jorge I. Domínguez, Cuba: Order and Revolution (Cambridge, Mass., 1978); González, Cuba Under Castro; Marifeli Peréz-Stable, The Cuban Revolution: Origins, Course and Legacy (New York, 1993); Andrés Suárez, Cuba: Castroism and Communism, 1959-1966 (Cambridge, Mass., 1967); and Thomas, Cuba: The Pursuit of Freedom.

20 For analysis of Guevara's writings see the introductions by Loveman and Davies, Guerrilla Warfare; Bonachea and Valdés, Che; Gott, Guerrilla Movements; Gerassi, Venceremos!; Donald Hodges, The Legacy of Che Guevara: A Documentary Study (London, 1975), pp. I1-75; Michael Lowy, The Marxism of Che Guevara: Philosophy, Economics and Revolutionary Warfare (New York, 1973); Sheldon B. Liss, Marxist Thought in Latin America (Berkeley, 1984), pp. 256-65; and Carlos Jesús Delgado, 'La concepción de la guerra revolucionaria de guerrillas de Ernesto Che Guevara', Casa de las Américas, no. I63 (Julio-Aug., 1987), pp. 25-36. Debray's works are analysed admirably by Harmut Ramm, Marxism of Régis Debray: Between Lenin and Guevara (Lawrence, Kansas, 1978). In addition, see the introduction by Blackburn to Strategy for Revolution and the collection of essays by prominent members of the Latin American Left in Huberman and Sweezy (eds.), Régis Debray and the Latin American Revolution.

21 Domínguez, To Make a World Safe for Revolution, pp. I $24-$ - . 
existed in their writings, they were neither significant nor a point of contention during the period 1959-67. According to Ramm and others, there existed, in fact, a large degree of co-authorship and co-editing of each others' works. The difficulty in separating their different perspectives is that authorship is often attributed to someone other than the actual author. For example, Bonachea and Valdés credit Guevara for authorship of the Second Declaration of Havana. 'Che developed a radical categorical imperative: The duty of the revolutionary is to make the revolution. To push history, to catalyze, is the function of the revolutionary' (italics in original). ${ }^{22}$

One could argue, however, that after Guevara's death and Fidel's condoning of the USSR's invasion of Czechoslovakia, a division emerged in the interpretation of Guevara writings. ${ }^{23}$ In Venezuela, Douglas Bravo of the FALN declared himself a guevarista but not a fidelista due to the Czech invasion. ${ }^{24}$ Thus, the divergences and connotations around such titles as guevarista or fidelista do not describe differences among Che and Castro, but rather peoples' interpretation of their ideas. Before proceeding to examine Guevara's writings, beginning with Guerrilla Warfare, it is necessary to touch briefly upon the empirical base from which the foco theory was drawn, the Cuban Revolution.

\section{The Cuban Revolutionary War}

As already indicated by Maurice Halperin, the 'official' history of the Cuban Revolution does not adequately address the role of the llano. While the llano has yet to receive the same attention of historians as the sierra, several works describe llano activities during the Revolution. ${ }^{25}$ Most works on the Cuban Revolution propagated by the state simply start with Batista's coup of io March I952, followed by Castro's Moncada assault, and then a narrative of the Rebel Army's activities from the December I956 Granma 'shipwreck', as Guevara put it, to Batista's flight into exile. Descriptions of the llano's role in the Cuban Revolution tend to focus on failures such as the Student Directorate's attack on the Presidential Palace in an attempt to assassinate Batista, the death of Frank País on 30 July

Bonachea and Valdés, 'Introduction', p. 28. I am confident that Bonachea and Valdés are aware that Castro authored the Second Declaration of Havana. Their point, and mine as well, is that their writings are so similar that they can be treated as by one author, or coauthors. Davies and Loveman make the same assumption: 'Guevara's primary message was that the duty of revolutionaries is to make revolution', p. I4; as does Lowy: 'Che's famous slogan: The duty of a revolutionary is to make revolution', p. $2 \mathrm{I}$.

${ }^{23}$ Hodges, Legacy of Che Guevara, pp. $3 \mathrm{I}^{-3}$.

24 Ratliff, Castroism and Communism, pp. IO3-I I.

25 For example, see the sources listed in fn. 2. 
1957, or the failure of the 9 April 1958 general strike. For example, Guevara writes: 'April $9^{\text {th }}$ was a painful failure which did not for a moment succeed in threatening the regime's stability. Far from it: after this tragic date the government was able to withdraw its forces and send them little by little to Oriente, to sow destruction as far as the Sierra., ${ }^{26}$ According to Guevara, insurgent activities of the llano not only failed to remove Batista from power, but in turn made the armed struggle even more difficult for the sierra.

After the revolutionary victory, Cuban historiography purposely ignored the important role groups other than the fidelistas played in elevating the revolutionary environment. The failure of each group to attain power served to put the burden of the revolution on Fidel Castro's shoulders, but with the burden also came support. Dominguez succinctly summarises how the sierra emerged as the leader of the revolution, partially by default.

The insurrectionist opposition to Batista gradually concentrated around the person of Fidel Castro through a mixture of competence, shrewdness, and luck. Castro's luck, in the form of accidental elimination of any alternative leaders, was remarkable. The Prío-financed attack on the Goicuría military barracks in Matanzas in April 1956 failed; Barquín's plot in April 1956 failed; the university student attack on the Presidential Palace in March 1957 failed and ended with the death of Havana student leader, a serious rival, José Antonio Echeverria; the Prio-financed landing of the Corintha expedition in May I957 failed; the Cienfuegos naval uprising failed; Frank País, leader of the Oriente provincial underground of the Twenty-Sixth of July Movement, Castro's most serious rival within the organization, was killed in July i 957; the general strike of April i 958 failed, and led to the subordination of the urban and labour underground to the leadership in the mountains. ${ }^{27}$

The important point to note is that Castro did not emerge as the undisputed leader in the struggle against Batista until the second half of 1958. According to González, prior to the failure of the general strike, the 'guerrillas remained a virtual appendage of the July 26 Movement', playing only a secondary role in the overall struggle. ${ }^{28}$ The initial revolutionary strategy of the July 26 Movement confirms González's statement. Throughout the revolutionary war, until April 1958, strategy called for armed struggle in the countryside to weaken the Batista dictatorship, with the final blow to be delivered by a general strike. After April, Castro placed primacy on the armed struggle, recalling the July 26 Movement urban leader in Havana, Faustino Pérez, to the Sierra Maestra. ${ }^{29}$ Nonetheless, Castro still recognised the importance of the llano,

26 Guevara, Reminiscences, p. 243.

27 Domínguez, Cuba: Order and Revolution, p. 27.

28 Gonzalez, Cuba Under Castro, p. 86. 
by his call for a general strike on I January 1959 to ensure a complete rebel victory. ${ }^{\mathbf{3 0}}$

One could surmise that Guevara, Castro and Debray did not incorporate the llano experience into the foco theory since they were not personally associated with the struggle in the city, and, as a result, did not grasp its overall significance in the overthrow of Batista. While there is surely some validity to this hypothesis, several examples tend to counter it. First, as cited above, Castro called for a general strike on I January 1959. Second, Castro's micromanagement political style, whereby he is personally involved and informed on all activities, suggests that he was well aware of llano activities. ${ }^{31}$ And third, there are several documents by Guevara from the first half of 1959 which acknowledge the importance of the llano.

On I9 January 1959, Guevara spoke at the headquarters of the Cuban Confederadion of Labour. 'I have not come here to be paid homage, but to pay tribute in the name of the Rebel Army to the Cuban working class. $^{\text {32 }}$ After recognising the role of the working class in the revolutionary struggle, he claimed Latin America ripe for the overthrow of dictatorships, but not the defeat of the bourgeoisie. This speech, given before Cuba joined the socialist camp, suggests that Castro and Guevara may have initially sought a workable relationship with the national bourgeoisie. Also, only three weeks before, Castro looked down on Cuba from the Sierra Maestra while Guevara battled in Las Villas; thus, they did not yet grasp their political strength to move against the national bourgeoisie and initially wanted to extend their political base in order to prevent any counterrevolutionary activity.

Less than ten days later, Guevara once again extolled the role of the urban working class in the Revolution. ${ }^{33}$ He commented on the important role of the llano in complementing the activities of the Rebel Army:

The victories of the Rebel Army and the great efforts of the underground created within the country a state of unrest... [These experiences] taught us a precious truth mainly that the Revolution did not belong to any one group in particular, but all of the Cuban people. Consequently all energies of our militants in the mountains and cities were aimed toward that end. ${ }^{34}$

30 See Castro's 'General Strike Proclamation', reprinted in Fidel Castro, Revolutionary Struggle, 1947-1958: Selected Works of Fidel Castro, vol. I, edited and with an introduction by Rolando E. Bonachea and Nelson P. Valdés (Cambridge, Mass., 1972), pp. 348-50.

31 Castro's writings in the Bonachea and Valdés edition and Franqui's Diario de la Revolución Cubana give evidence of Castro's daily awareness of llano activities.

32 The speech appeared in El Mundo, 20 Jan. 1959, pp. I-8. Reprinted in Bonachea and Valdés, Che, 'Honoring the Labor Movement', p. 195.

33 Speech delivered to the Sociedad de Nuestro Tiempo on 27 Jan. 1959. Reprinted in Bonachea and Valdés, Che, 'Social Ideas of the Rebel Army', pp. 196-204.

${ }^{34}$ Ibid., p. 198. 
Additionally, Che remarked that due to repression, the peasants joined the Rebel Army resulting in 'an army of civilians [becoming] an army of peasants'. In this and the previous speech, Che pointed out the role that other groups played in the revolution, but at the same time emphasised that the Rebel Army led the struggle in the vanguard position.

Because the later history of the Cuban Revolution and the foco theory minimised the role of the llano, these speeches can be interpreted as attempts by the fidelistas to increase their base of support by bringing other groups under the umbrella of the overall struggle. Guevara's recognition of the importance of the working class coincided with the expulsion by anti-communist July 26 Movement elements of Popular Socialist Party (PSP), members of the Executive Committee of the Confederation of Cuban Workers (CTC), and their replacement by July 26 Movement leaders. ${ }^{35}$ Also, classification of the Revolution as against a dictatorship and not against the national bourgeoisie, reflected the representation of the first cabinet, 'lawyers, judges, economists, ortodoxos, ... and social activists'. ${ }^{36}$

In two separate interviews in April 1959, Guevara began to describe the Revolution, somewhat cautiously, along class lines by denouncing those sectors of the national bourgeoisie who opposed changes, such as agrarian reform. ${ }^{37}$ According to Ramm, however, Guevara continued to deny that the Cuban Revolution 'was a class revolution, its only enemies were those who opposed land reform - latifundistas and the reactionary bourgeoisie'. ${ }^{38}$ Guevara specifically identified the reactionary bourgeoisie and did not condemn the bourgeoisie in general. These two interviews reflect a noticeable shift in Guevara's thought from recognition of the role of the bourgeoisie in the revolution to regarding them as neither an ally nor an enemy in the post-insurrectionary stage. Later, he would identify the bourgeoisie as an obstacle to the construction of socialism.

Again, these changes serve as an index to national politics. In April, the July 26 Movement accused the PSP of bourgeois tendencies and collaboration with Batista. ${ }^{39}$ Guevara apparently anticipated the bourgeoisie's unfavourable reaction to the Agrarian Reform Law of 17 May 1959. The Law resulted in the resignation of five moderate members of the July 26 Movement who held positions in the cabinet. ${ }^{40}$ Two months later, Castro forced the resignation of President Manuel Urrutia,

35 Pérez-Stable, Cuban Revolution, p. 70.

36 Ibid., p. 62.

37 The interviews were conducted on 18 April 1959 and 28 April 1959 and appear in Bonachea and Valdés, Che, 'A New Old Che Guevara Interview', pp. 368-76; and 'Interview by Telemundo Television', pp. 378-83.

38 Ramm, Marxism of Régis Debray, p. 35.

39 Pérez-Stable, Cuban Revolution, p. $7 \mathrm{I}$.

40 González, Cuba Under Castro, p. 97, fn. 33. 
severely weakening bourgeoisie representation in the revolutionary government. ${ }^{41}$ By early 1960 the fidelistas firmly controlled all the important positions of power, ready to radicalise the Revolution. In this increasingly radical environment, where the sierra held government positions they both did and did not deserve, Guevara wrote Guerrilla Warfare.

\section{Guerrilla Warfare ${ }^{42}$}

From the first page of the first chapter of Guerrilla $W$ arfare Guevara clearly spells out the fundamental lessons of the Cuban Revolution.

(I) Popular forces can win against the army.

(2) It is not necessary to wait until all the conditions for making revolution exist; the insurrection can create them.

(3) In underdeveloped America the countryside is the basic area of armed fighting. ${ }^{43}$

The first lesson simply stated that a guerrilla army can defeat a regular army. The second lesson caused Marxists to claim heresy as Che advocated speeding up history and giving primacy to subjective conditions over objective ones. ${ }^{44}$ And the third lesson called for the leadership, the base, and the theatre of revolutionary struggle to be located in the mountains directed by the sierra.

The overall focus of the manual lies in lessons number two and three. Guevara even calculated the number of guerrillas necessary to form a foco and begin the armed struggle:

The minimum number with which it is possible to initiate a guerrilla war can be mentioned. In my opinion, considering the normal desertions and weakness in spite of the rigorous process of selection, there should be a nucleus of 30 to so men; this figure is sufficient to initiate an armed fight in any country of the Americas with their conditions of favourable territory for operations, hunger for land, repeated attacks upon justice, etc. ${ }^{45}$

The above quote clearly draws from the sierra experience and does not account for the important role played by urban groups. He then explains that the guerrilla will be supplied internally by the peasants, not giving credit to the essential role Frank País and the Santiago July 26 Movement played in arming and supplying recruits following the disaster at Alegria

41 Ibid., pp. 98-9.

42 Che Guevara, Guerrilla Warfare (Lincoln, Nebraska, I985). $\quad{ }^{43}$ Ibid., p. 45.

44 Marx warned against such attempts: "Their activities consist precisely of trying to anticipate the revolutionary process, to carry it on to a crisis artificially, and to impose a revolution without the conditions for a revolution being present. For them, the only condition for revolution is sufficient organization of their conspiracy.' Quoted in Ratliff, Castroism and Communism, p. 179.

45 Guevara, Guerrilla Warfare, pp. I 5 7-8. 
de Pío. ${ }^{46}$ Nonetheless, Che does not completely ignore the role of the urban underground or their potential, stating that 'the city's masses of organized workers should not be underrated ' ${ }^{47}$ Guevara also spelled out the essential duties of the Ilano in relation to propaganda, intelligence and sabotage, but all the while emphasising their subordination to the directives of the sierra.

Che developed a democratic corollary to Guerrilla Warfare, already cited by Castañeda, which prevented the development of the armed struggle:

When a government has come to power through some form of popular vote, fraudulent or not, and maintains at least an appearance of constitutional legality, the guerrilla outbreak cannot be promoted, since the possibilities of peaceful struggle have not yet been exhausted. ${ }^{48}$

I will later discuss when and why Che abrogated the democratic exclusion.

Guevara also briefly touched on a point that would later be further explored by Debray, the vanguard foco in place of the Leninist vanguard party. 'The guerrilla fighter, as a person conscious of the role in the vanguard of the people, must have a moral conduct that shows him to be a true priest of reform. ${ }^{49}$ The vanguard foco, however, does not solely radicalise the peasantry; in addition, the peasants serve to politicise the guerrilla fighters and vice versa in a symbiotic revolutionary relationship:

It happens that a genuine interaction is produced between these leaders, who with their acts teach the people the fundamental importance of the armed fight, and the people themselves who rise in rebellion and teach the leaders these practical necessities of which we speak. Thus, as a product of this interaction between the guerrilla fighter and his people, a progressive radicalization appears which further accentuates the revolutionary characteristics of the movement and gives it a national scope. ${ }^{50}$

In summary, Guerrilla Warfare places primary importance on the role of the foco in creating conditions for revolution. Both the base of operations and leadership are to be located in the sierra. Guerrilla Warfare did not totally exclude the role of the llano in the revolutionary struggle, nor did it adequately accredit it. The democratic corollary stated that guerrilla movements could not be pursued in countries such as Mexico, Costa Rica, Chile and Venezuela. While Guerrilla Warfare is not a true representation of the Cuban Revolution, it does present most of its principal phenomena, albeit in a distorted manner.

It is important to note that throughout the work Che emphasised he was drawing from the Cuban Revolution: 'I repeat once more, it is our

46 At Alegría de Pío Castro's forces were reduced from 82 to the mythical figure of 12 only days following the Granma landing. During December 1956 and January 1957 País was Castro's lifeline in the Sierra Maestra.

49 Ibid., p. 80.

50 Ibid., p. $8 \mathrm{I}$.

48 Ibid. 
Cuban experience which speaks through me; new experiences can vary and improve these concepts. We offer an outline, not a bible. ${ }^{51}$ This point has two important implications. First, since the Cuban experience 'spoke through Che', he was retelling the Cuban Revolution, and thus the ahistorical elevated role of the sierra and the minimised role of the llano served to legitimise fidelista monopolisation of power. Second, Guevara's emphasis on representing an 'outline' and not a 'bible' would later be ignored as the foco theory became increasingly theoretical and dogmatic. ${ }^{\mathbf{2}}$ The remainder of the article will proceed by examining the changes which occurred in the foco theory from the publication of Guerrilla Warfare until Che's death in Bolivia in 1967 , by juxtaposing these corrections or distortions (depending on your interpretation) against a political and historical backdrop.

\section{'Sierraisation' of the Foco, 1960-2}

The three years following the publication of Guerrilla Warfare witnessed a strong and gradual shift towards increasing the importance of the sierra in the foco theory. I will label this trend and period 'sierraisation' of the foco owing to the elevated role of the sierra in the foco theory. The process by which the sierra became increasingly important in the armed struggle was not limited solely to the period $1960-2$, and is a recurring theme until I 967 ; nonetheless, these years represent the time frame for the most commonly marked changes in the foco theory. 'Sierraisation' of the foco, was followed by 'Marxianisation' of the foco, $1963^{-5}$, and 'internationalisation' of the foco, $1965-7$; the later two periods will be analysed in the following sections. By employing this categorisation and periodisation I am not implying that these were the only types of changes made during the indicated periods, for there is considerable overlap. Despite the deficiencies in this categorisation and periodisation, the approach will assist in analysing the foco theory and identifying its major trends. ${ }^{53}$

51 Ibid., p. I 32.

52 Fidel and Che criticised allegiance to Marxian orthodoxy only to demand strict following of their own formulation. 'It appears as though slavish obedience to old doctrine was replaced by equally inflexible awe for a new one, whose superiority may have lain in its psychological immediacy and temporal proximity, rather than its political efficiency.' 'Timothy P. Wickham-Crowley, 'A Sociological Analysis of Latin American Guerrilla Movements, I956-1970', unpubl. PhD diss., Cornell University, $198 \mathrm{I}$, p. 68.

53 Unsurprisingly, these categories correspond to Guevara's primary roles in the Cuban government. Che became president of the National Bank in 1959 and quickly surrounded himself with veterans of the sierra. From 1962 to 1965 , Che challenged many of the 'old Communists' during the 'Great Debate', justifying his unorthodox Marxism by quoting the early writings of Marx. And from ig65 onward, Che made several trips throughout the world where he personally sought to 'export' the Cuban Revolution. 
In March 1960, Guevara spoke on television and affirmed that for Cuba to be politically sovereign, she would have to be economically independent from the metropolises, specifically the United States. ${ }^{54}$ According to Guevara, Cuba would have to break free from her colonial economic structure of providing raw materials and dependence on sugar exports in order to be politically independent. Although many agreed with Guevara's economic plan of diversification, several within the government, both Marxist and non-Marxist, but all primarily former bourgeois representatives of the llano, voiced opposition. Disagreements, however, were not welcomed as demonstrated by Guevara replacing Felipe Pazos as president of the National Bank in the fall of 1959. The fidelistas of the sierra chose the correct path in the armed struggle and assumed they could do the same in the economic struggle as well.

Several months later, Guevara turned his attention to the working class of Cuba and its role in industrialisation. ${ }^{55}$ The speech incorporated the working class into the revolution via the foco in the post-insurrectionary stage. Hodges carefully analysed the speech claiming the 'original aim [of the revolutionary movement] to mobilize the peasants through a programme of agrarian reform subsequently shifted during its constructive stage to the principle of mobilizing the workers through a program of industrialization'. ${ }^{56}$ The speech, according to Hodges, justifies the sierra bias of the foco theory by claiming that although the proletariat does not play the primary role in the insurrectionary stage, its participation will be fundamental in the post-revolutionary period. ${ }^{57}$

The increasing polarisation between the United States and Cuba is reflected in Guevara's speech made at the First Congress of Latin American Youth in July $1960 .^{58}$ Earlier in the year, Mikoyan visited Havana, establishing the first trade agreements between the two countries and confirming Washington's suspicion of the communist turn in the Cuba Revolution. ${ }^{59}$ In June, after Texaco, Shell and Standard Oil refused to refine Soviet crude oil, the Cuban government confiscated their holdings. A rapid deterioration of relations between the two countries followed, in which the sugar quota was cut and United States properties

54 Speech delivered on the television programme 'Universidad Popular', 20 March 1960 and printed the following day in Revolución, pp. $1-8$. Reprinted in Bonachea and Valdés, Che, 'Political Sovereignty and Economic Independence', pp. 21 3-29.

55 Speech delivered to the Havana assembly of workers on 18 June 1960 and printed in Obra Revolucionario, 1960, no. II. Reprinted in Venceremos!, as 'On Sacrifice and Dedication', pp. 92-108.

${ }^{56}$ Hodges, Legacy of Che Guevara, p. 28.

57 Ibid.

58 Speech delivered to the First Congress of Latin American Youth on 28 July 1960 and printed in Obra Revolucionario, 25 August 1960, pp. 13-20. Reprinted in Bonachea and Valdés, Che, 'Development of a Marxist Revolution', pp. 246-56.

59 González, Cuba Under Castro, pp. $123-4$. 
nationalised. ${ }^{60}$ Castro realised by late 1959 and the first months of 1960 that if Cuba wanted to follow through with its radical reforms it would have to attract the security of the Soviet Union. Thus, Cuba began a process whereby its leaders 'seduced' the Soviets by quoting Marx and Lenin and carrying out anti-United States policies. ${ }^{\mathbf{6 1}}$

Guevara's speech, in which he neither labelled the revolution socialist nor claimed that it was not socialist, reflected contemporary politics and expediency. Che developed a masterful compromise:

[I]s the Cuba Revolution communist? Some will wishfully state this is so, or that it is moving in that direction. Others, perhaps feeling disappointed, will also answer in the affirmative, and still others with disappointment will think that this is not a communist revolution. Others, still hoping, will answer no. And if someone asks me if this Revolution before your eyes is a communist revolution, I would reply (leaving aside all the accusations made by imperialism and the colonial powers who try to bring confusion to everything) that we realize that this revolution, if it happens to be Marxist - and listen carefully, I say Marxist - is thus because it discovered by its own means the path that Marx pointed out. [emphasis added] ${ }^{62}$

The dominant theme of the speech, clearly indicated in the above quote, is that the truths of Marxism are not understood solely from studying Marx; rather, they can be naturally discovered through the revolutionary process. Not only is this statement interesting because of its claim of the natural discovery of Marxism, but the audience was made up of students. It can be deduced that Che was indirectly mocking those who simply studied Marx and did not put his ideas into practice.

The speech could very easily be placed in the category of 'Marxianisation' of the foco; nonetheless, I believe it has important reference for the 'sierraisation' of the foco. Guevara advocated going beyond simply studying Marx by making an existential commitment to revolutionary action. Guevara implied that because the guerrillas were not as versed in Marxism as the PSP, the Cuban Revolution occurred. Thus, as a result of subjective conditions, the foco brought about the Cuban Revolution and, in the process, discovered the 'path that Marx pointed

60 Pérez-Stable, Cuban Revolution, p. 8o.

61 On 16 October 1959 Alexandr Alexeev visited Cuba to arrange Mikoyan's visit. "Alexeev reports that he was "stunned" when Castro quoted Marx and Lenin at their October 16 meeting "because at that time we could not even imagine that he knew Marxist theory". Few Soviets knew much about Cuba; most were sceptical of the revolutionaries' credentials because so many of them were 'bourgeois liberals.", Guevara told Alexeev that 'the only way to achieve Cuba's full independence was to build a socialist society'. Domínguez, To Make $A$ World Safe for Revolution, pp. 20-3. Also see González, Cuba Under Castro, p. 146 for insightful comments on Fidel's Marxist credentials, or, more aptly, lack thereof.

${ }^{62}$ Guevara, 'Development of a Marxist Revolution', p. 247. 
out'. In the end, Guevara claimed that because he had learned Marxism in its appropriate laboratory of revolutionary action, rather than through books or party cells in the llano, his Marxian credentials were more valid. ${ }^{63}$

Guevara's speech to the First Congress of Latin American Youth, later became more forcefully represented in an article which appeared in October $1960 .^{64} \mathrm{He}$ specifically sought to reply to the Leninist revolutionary doctrine that 'without a revolutionary theory there is no revolutionary movement', which refuted his contention of naturally discovering Marxism and the primacy of military actions over political ones:

This is a unique Revolution which some people assert contradicts one of the most orthodox premises of the revolutionary movement expressed by Lenin: 'without a revolutionary theory, there is no revolutionary movement'. It would be suitable to state that a revolutionary theory, as the expression of a social truth, is beyond any enunciation of it, that is to say, the revolution can be made if the historical realities are interpreted correctly and if the forces involved are utilized correctly. ${ }^{65}$

To be direct, Guevara claimed Lenin was wrong. The Cuban Revolution demonstrated that there could be a revolutionary movement without a revolutionary theory. He then went on to claim: 'One should be a "Marxist" as naturally as one is a "Newtonian' in physics, or a "Pasteurian" in biology considering that if new facts determine new concepts these new concepts will never take away that path of truth which the older concept had. ${ }^{\mathbf{6 6}}$ Che emphasised pragmatism rather than adherence to dogmatic interpretations. In an interview with Laura Berquist in November 1960 , he once again referred to the importance and validity of discovering truth through revolutionary praxis. "Where one really learns is in a revolutionary war; every mistake teaches you more than a million volumes of books. You mature in the extraordinary university of experience. ${ }^{\mathbf{6} 7}$

Guevara's constant return to the maxim of discovering truth through revolutionary action served in part to defend himself from his Marxian critics, but also, and perhaps more importantly, to remind others of the inactivity of the PSP in the revolutionary war. The 'old Communists' did not join the armed struggle until late 1958 and played a largely

${ }^{63}$ Guevara, of course, did not dismiss the necessity for reading Marx or revolutionary theory, which he often did on his own campaigns in addition to other genre. However, if these theories were not put into practice in the revolutionary laboratory they would only remain ideas of bourgeois abstraction.

64 Ernesto Che Guevara, 'Notas para el Estudio de la Idelogía de la Revolución Cubana', Verde Olivo, 8 Oct. 1960, pp. 10-14. Reprinted in Bonachea and Valdés, Che, 'Notes for the Study of the Ideology of the Cuba Revolution', pp. 48-56.

${ }^{65}$ Ibid., p. 48.

${ }^{66}$ Ibid., p. 49.

${ }^{67}$ Bonachea and Valdés, Che, 'Interview with Laura Berquist (\# I)', Pp. 384-7. 
insignificant role. Following the revolutionary victory, Castro resurrected the PSP for administrative reasons and to garner Soviet recognition. In the process, however, the PSP represented a force which could, and did, challenge Castro's political authority. The foco theory's supremacy of subjective conditions and the concentration of political activity in the countryside served to check PSP power and reinforce their historically unrevolutionary attitude.

In April 1961, before the Bay of Pigs invasion, Guevara answered his critics once again with the article 'Cuba: Exceptional Case or Vanguard in the Struggle Against Colonialism'. ${ }^{68}$ The article was addressed to the Latin American communist parties who claimed, just as the PSP had, that the conditions were not appropriate for armed revolution. Guevara recognised two 'exceptional characteristics' of the Cuban revolution: (I) the leadership of Fidel Castro; and (2) a somewhat 'proletarianised' peasantry. These aside, the objective conditions in Cuba at the time of the revolution could be found throughout Latin America. Guevara summarised the hemispheric universality of objective conditions from the 'Rio Bravo to the South Pole' as 'Hunger of the People':

Weariness from being oppressed, abused, and exploited to the maximum; weariness from selling one's labor day after day for fear of becoming part of the great mass of the unemployed - all so that maximum profit is squeezed from each human body only to be squandered in the orgies of the owners of capital. ${ }^{69}$

Guevara claimed that the common denominator of 'Hunger of the People' made almost all of Latin America ripe for revolution. Only the '[s]ubjective conditions were missing in America - the most important being the consciousnes of the possibility of victory through violent struggle against the imperialist powers and their internal allies' ${ }^{70}$ According to Guevara, objective conditions were present everywhere, but only in Cuba through the exceptional leadership of Castro were the subjective conditions developed to carry out the revolution. Repeatedly, Guevara emphasised the primacy of subjective conditions and the necessity for the political struggle to be subordinate to the armed struggle. Also, he touched upon his theme once again of discovering 'through revolutionary praxis the correct methods of achieving socialism'.

Although addressed to Latin American communist parties, Guevara's article solicited a response from PSP leader Aníbal Escalante in Verde Olivo, the official organ of the Cuban Armed Forces. The article, entitled 'The True Breeding Ground of Communism', challenged Guevara's notion of the discovery of the truths of Marxism through revolutionary struggle. More importantly, Escalante attacked Guevara's primacy on 68 Verde Olivo, 9 April 196 I, pp. 22-9. Reprinted in Bonachea and Valdés, Che, pp. 57-70. 69 Ibid., p. 62.

${ }^{70}$ Ibid., p. 63. 
subjective conditions in determining the revolutionary victory in Latin America - amazingly citing the Cuban Revolution as a counter example. ${ }^{71}$ Escalante claimed that the 'exceptional' nature of the Cuban Revolution was not subjective, as Guevara had suggested; rather, Cuba's objective level of capitalist development was one of the highest in Latin America. Escalante's open challenge to the validity of the foco theory presaged the division between the 'old Communists' and the veterans of the sierra, which would later become fully manifest in the 'Escalante Affair'.

In January 1962, the Organisation of American States (OAS) adopted several resolutions which directly criticised Cuba, such as: 'The principles of Communism are incompatible with the principles of the Inter-american system', and the 'present government of Cuba, which has officially identified itself as a Marxist-Leninist government, is incompatible with the Inter-american system '. ${ }^{72}$ Castro wasted no time in responding to hemispheric isolation when in February 1962 he released his famous Second Declaration of Havana claiming the 'duty of every revolutionary is to make the revolution'. Any support previously given secretly by Castro to insurgent groups was now done openly and defiantly. From 1962 until Guevara's death in October 1967, Cuba actively pursued a policy of 'exporting the revolution' through hosting numerous conferences, supporting hemispheric and international organisations, and providing arms and funds to insurgents. ${ }^{73}$

While the Second Declaration of Havana represented the strongest statement to date on the role of the subjective conditions, Edward González noted a passage which tends to contradict the 'sierraisation' of the foco:

[T] he peasantry is a class which, because of the uncultivated state in which it lives, needs the revolutionary and political leadership of the working class and revolutionary intellectuals for without them it would not by itself be able to plunge into the struggle and achieve victory. [emphasis added by González] ${ }^{74}$

González then went on to explain in a footnote that 'the reference to the leadership of the working class appears to have been a concession to communist orthodoxy: The Second Declaration of Havana came on the

71 See Draper, Castroism: Theory and Practice, pp. 84-99 for Escalante's challenge to the Guevara line.

72 OAS actions followed Castro's 2 December 196 I claim that he was a Marxist-Leninist. Domínguez, To Make A World Dafe for Revolution, p. 27.

73 Guevara repeated and confirmed most of the ideas of the Second Declaration of Havana in a speech given in May 1962 . He recommended that Cuba seek allies among their 'respective peoples', calling for Cuba to encourage and support armed struggle as part of 'Cuba's own strategy of defense'. Ernesto Che Guevara, Obras Completas, 1957-1967, vol. II, 'La influencia de la Revolución Cubana en la América Latina' (Havana, 1970), pp. $469-92$.

${ }^{74}$ Quoted in González, Cuba Under Castro, p. 93. 
heels of Castro's public conversion to Marxism-Leninism in his speech of 2 December 196r'. ${ }^{75}$ The 'concession', however, was highly restricted because the following month Castro moved against the leading proponents of communist orthodoxy, Aníbal Escalante and other PSP members who held important positions in the Integrated Revolutionary Organisation (ORI). In the end, as González remarks, the statement should be regarded as a 'concession' which does not represent a significant reorientation of the foco theory.

Another interesting aspect of the Second Declaration of Havana is its childlike portrayal of the peasantry. The earlier statement of Guevara in Guerrilla Warfare of 'a genuine interaction' whereby 'leaders teach the people' and 'people teach the leaders' is replaced by the stronger vanguard position that the peasantry need appropriate 'revolutionary' and 'political leadership' owing to their 'uncultivated state'. Overall, the Second Declaration of Havana follows the general trend of increasing emphasis on subjective conditions and the role of the foco in developing them.

In March 1962, in the 'Escalante Affair', Cuba experienced its most decisive government shake up since the tense months of June-November 1959 which witnessed Manual Urrutia's forced resignation and rebel leader Hubert Matos's imprisonment. ${ }^{76}$ After Fidel declared the socialist nature of the Cuban Revolution, only days before the Bay of Pigs invasion, a proto-communist party was created combining the July 26 Movement, the Revolutionary Student Directorate, and the PSP into one apparatus, appropriately called the ORI. Pérez-Stable logically remarks that the PSP was given significant authority within the ORI since they had the personnel, experience in organising parties, and ' knew about socialism, vanguard parties, and the Soviet Union, [while the] July 26 Movement and Revolutionary Student Directorate did not'. ${ }^{77}$ Surprisingly, Anibal Escalante who characterised the Cuba Revolution as 'bourgeoisdemocratic' and advocated the inclusion of the 'national bourgeoisie' because the 'socialist transformation was not foreseen in the immediate future', headed the task of creating the ORI ${ }^{78}$ The ORI was formed in July I96I, but its national directorate was not announced until 9 March 1962. Escalante gave preference to the 'old communists' who received ten seats on the 25 -member National Directorate. The PSP within the ORI clearly threatened Castro's authority. Two weeks after the selection of the

75 Ibid., p. 93, fn. 24.

76 The discussion of the March 1962 'Escalante Affair' is taken from the following: Domínguez, Cuba: Order and Revolution, pp. 210-14; González, Cuba Under Castro, pp. 100-4; Pérez-Stable, Cuban Revolution, pp. 98-101; and Suárez, Castroism and Communism, pp. 146-53.

77 Pérez-Stable, Cuban Revolution, p. IоI.

78 González, Cuba Under Castro, pp. ıоo-I. 
ORI National Directorate, Castro attacked Escalante on national television, removing him from power. ${ }^{\mathbf{7 9}}$

While the division between the 'old communists' and the fidelistas could be found in various issues of the 'Escalante Affair', apparently an important one was the foco theory. After the July 26 Movement gained clear control of the ORI, membership in the party required 'acceptance of the two Declarations of Havana as the party's program'. ${ }^{80}$ The very fact that this was required reflects the strong division the foco theory created within Cuban politics and the need to demand its adherence.

'Sierraisation' of the foco, in summary, defines the process whereby the sierra members of the armed struggle played an increasingly elevated role in the foco theory. This phenomenon resembled a similar tempo in national politics, and at times, was even a part of it. Guevara's unfavourable perception of the bourgeoisie in the armed struggle deprived the llano of an important role in the overall struggle. In addition, Che's notion of the natural discovery of Marxism through armed struggle reinforced and justified his contention that military action precedes political action; the former crystallised the latter. In the following two sections it becomes increasingly difficult to draw similarities between changes in the foco theory and national politics. The primary explanation for this difficulty is that Cuban politics is notably less dynamic and volatile as a result of the fidelistas' consolidation of power.

\section{'Marxianisation' of the Foco, 1962-s}

Following the 'Escalante Affair', Guevara gave a speech to the Department of State Security which identified an additional set of conditions to initiate the armed struggle. ${ }^{81}$ Guevara cited factors which show a pronounced Leninist shade such as the extent of imperialist penetration, the geographical distance from the Yankee metropolis, and the influence of Cuban revolutionary ideas. Hodges claims that 'Che identified an entirely new set of factors for the viability of armed struggle'.82 Personally, I feel Hodges's statement is too strong; nonetheless, there is an apparent shift in Guevara's writings on guerrilla

79 Castro accused Escalante of not organising a party, but a 'straight jacket', a 'yoke', a 'counterrevolutionary monstrosity', for promoting 'sectarianism', and for attempting to make the ORI 'a machine for personal aims'. Suárez, Castroism and Communism, p. I 52. Guevara echoed Castro's denunciation of Escalante in a speech the following month: 'There had appeared throughout the country, as a baneful vice that it was necessary for us to eliminate completely, aloofness from the masses, dogmatism, sectarianism. Because of them, we were threatened by bureaucratism.' Quoted in Lowy, Marxism of Che Guevara, p. 18, fn. 9.

80 Domínguez, Cuba: Order and Revolution, p. 2 I I.

81 Guevara, 'La Influencia de la Revolución Cubana en la América Latina', pp. 469-92.

82 Hodges, Legacy of Che Guevara, p. 23. 


\section{6i4 Matt D. Childs}

warfare in which it becomes increasingly cloaked in the Marxian lexicon. I will refer to this shift as 'Marxianisation' of the foco, 1962-5. The 'sierraisation' of the foco still operated during this period and remained a strong and noticeable theme of the writings, but the tone of the works reflected a clear Marxian influence. My purpose is not to make an assessment of Guevara's Marxism or Marxian revolutionary theory, but simply to distinguish Che's later writings from his earlier ones by the increasing presence of Marx. The 'Marxianisation' of the foco coincided with two events which influenced this trend: first, the 'Great Debate'; and second, the arrival of Régis Debray.

An article written by Guevara in October 1962, during the Cuban missile crisis, reflects both the 'Marxianisation' and the 'internationalisation' of the foco. ${ }^{83}$ Any previous notion of cooperation with the national bourgeoisie in the revolutionary struggle was dropped:

The frightened bourgeoisie is faced with a terrible choice: submission to foreign capital or destruction by domestic popular forces. This dilemma has been accentuated by the Cuban revolution; through the polarization created by its example, the only alternative left is to sell out. When this takes place, when the pact is sanctioned, the domestic revolutionary forces ally themselves with the most powerful international reactionary forces, and the peaceful development of social revolution is prevented. ${ }^{84}$

Guevara claimed the very example of the Cuban Revolution changed the overall revolutionary strategy for Latin America, preventing an alliance with the national bourgeoisie. As a result, the revolution would now take on a more pronounced class structure. Guevara also declared that the Latin American revolution would be socialist and thereby alienated progressive, yet anti-communist, members of the opposition.

Guevara's frequent criticisms of the national bourgeoisie and communist parties in Latin America, in addition to the restructuring of the Cuban government after the 'Escalante Affair', are reflected in Guevara's prologue to El Partido Marxista-Leninista. The work takes considerable liberty in describing the differences between the sierra and the llano during the revolutionary war. $^{85}$

There was within the revolutionary movement a series of contradictions which we call the sierra and llano which manifested themselves in diametrically different analyses of the elements considered fundamental to decide armed struggle... the

83 The article entitled 'Tactics and Strategy of the Latin American Revolution', according to the Cuban government, was written during the missile crisis of October 1962, yet remained unpubished until after Guevara's death. Reprinted in Bonachea and Valdés, Che, pp. $77^{-88}$.

84 Ibid., p. 79.

85 Ernesto Che Guevara, 'Prológo', El Partido Marxista-Leninista (Havana, 1963). Reprinted in Bonachea and Valdés, Cbe, 'The Role of a Marxist-Leninist Party', pp. IO2-II. 
sierra was ready to engage the army as often as necessary...llano favored generalized armed struggle culminating in a revolutionary general strike that would expel the Batista dictatorship and establish a government of 'civilians' converting the new army into an apolitical institution.... These differences were deeper than tactical discrepancies: the Rebel Army was already ideologically proletarian and thought as a dispossessed class; the urban leadership remained petty bourgeois with future traitors among its leaders. ${ }^{86}$

Clearly this was an exaggeration of the Cuban experience. The sierra/llano dichotomy, while existing during the revolutionary war, was not as decisive or as class based as Guevara implied. Indeed, to claim the 'Rebel Army was already ideologically proletarian' is a severe distortion of the Cuban reality. Biographical research on membership of both the July 26 Movement and the PSP detailing occupation and class standing, as well as parents, clearly demonstrates fidelista leadership to be overwhelmingly bourgeois, with the PSP more representative of the proletarian class. ${ }^{87}$

An implicit assumption of the 'prologue' to El Partido MarxistaLeninista, pointed out by Bonachea and Valdés, is that the countryside has a 'proletarianising' effect, whereas the city encourages the process of 'embourgeoisement'. ${ }^{88}$ Unfortunately, no dissenting opinion within Cuba contested this analysis, as occurred earlier concerning Guevara's natural discovery of Marxism through revolutionary action. Apparently, the 'Escalante Affair' served to silence anyone who dissented. ${ }^{89}$ The national bourgeoisie were portrayed once again in a pejorative manner because 'faced with the dilemma of choosing between the people and imperialism, the weak national bourgeoisie have chosen imperialism' ${ }^{90}$

Beginning in 1962 and continuing until 1965, a 'Great Debate' took place in Cuba over economic policy. In brief, the debate centred around how to construct socialism. Guevara and others advocated pursuing a policy of moral incentives to construct the 'new man' and develop the communist conciencia. Carlos Rafael Rodríguez and other members of the PSP advocated material incentives. The debate stretched over three years

86 Ibid., pp. 106-7.

87 David Crain, 'The Course of the Cuban Heresy: The Rise and Decline of Castroism's Challenge to the Soviet Line in the Latin American Marxist Revolutionary Movement, 1963-1970', unpubl. PhD diss., Indiana University, 1971, p. 296; and WickhamCrowley, 'Sociological Analysis of Latin American Guerrilla Movements', pp. $21-3$. Universo Sánchez and Crescencio Pérez are the notable members of the July 26 Movement who could be considered proletarian.

88 Bonachea and Valdés, 'Introduction', Che, p. 16. The editors refer to Guevara's unorthodox Marxian formulation as 'guerrilla communism'.

89 The lessons of the 'Escalante Affair' were reinforced in March 1964 when former PSP member Marcos Rodríguez was arrested and sentenced to death for having revealed to Batista's police force the whereabouts of the surviving students from the Revolutionary Directorate who launched the attack on the Presidential Palace on 13 March 1957. González, Cuba under Castro, p. i०3.

90 Guevara, 'Role of Marxist-Leninist Party', p. ıоs. 
and reflected a case of limited pluralism. However, with Guevara making statements that the struggle in the llano resulted in the 'embourgeoisement' of the revolution and describing the national bourgeoisie as 'weak', the position of moral incentives was strengthened. In the end, moral incentives triumphed in the 'Great Debate', with Castro advocating Guevara's position in $1966 .^{91}$

In September 1963, Guevara wrote, 'Guerrilla Warfare: A Method', which can be considered a preface to the second edition of Guerrilla Warfare since it repeated and confirmed the three lessons of the earlier work. ${ }^{92}$ He made, however, two important changes. First, Che dropped the democratic corollary, previously discussed, which served to check the development of guerrilla insurgencies. He now argued: "We should not allow "democracy" to be utilised apologetically to represent the dictatorship of the exploiting classes. ${ }^{, 93}$ Previously, in Guerrilla Warfare, Guevara claimed that democracy 'fraudulent or not' caused 'the guerrilla outbreak' to 'not be promoted, since the possibilities of peaceful struggle have not been exhausted'. ${ }^{94}$ Once Cuban politics became Marxist, it was only natural for Guevara to dismiss democracy as an obviation for armed struggle. For if Che continued to regard democracy as the effective preventive measure to counter guerrilla warfare, he would be indirectly claiming the impossibility of revolutionary conditions in democratic political systems, and further, dismissing the role of objective capitalist exploitation and subjective commitment to revolutionary action which are paramount in all Marxist revolutionary theorists.

The second point, primary emphasis of the article, and a nuance in his writings, is the desired polarisation of society into well defined classes from which a socialist revolution would be waged:

The equilibrium between oligarchic dictatorship and the popular pressure must be changed. The dictatorship tries to function without resorting to force. Thus, we must try to oblige the dictatorship to resort to violence, thereby unmasking its true nature as the dictatorship of the reactionary social classes. This event will deepen the struggle to such an extent that there will be no retreat from it. The performance of the people's forces depends on the task of forcing the dictatorship to a decision - to retreat or unleash the struggle. ${ }^{95}$

Once class antagonisms were fully developed, the guerrilla war would ensue and after victory society would already be ready for the construction of socialism. The language, flavour, and frequent citations of Lenin, Marx and Engels all represent a distinct tone not present in Guerrilla Warfare.

\footnotetext{
91 For an examination of the 'Great Debate' and the various individuals involved see Bertram Silverman (ed.), Man and Socialism in Cuba: The Great Debate (New York, 1971).

92 Reprinted in Bonachea and Valdés, Che, 'Guerrilla Warfare: A Method', pp. 89-103.

93 Ibid., p. 93.

94 Guevara, Guerrilla Warfare, p. 48.

95 Guevara, 'Guerrilla Warfare: A Method', p. 95.
} 
The switch is a clear reflection of national and international politics. In 1960, when Guerrilla Warfare was published, the socialist nature of the Cuban Revolution had yet to be declared. By 1963 , on the other hand, the Soviet Union had admitted Cuba to the socialist camp. Just as politics went through a process of 'Marxianisation', so did the foco theory ${ }^{96}$ Also, the foco theory was still criticised and not accepted by orthodox Communists. Guevara's repeated citation of Lenin and Marx strengthened his defence against accusations of heresy.

An additional point which emerged during the period i $962-9$, marking a clear break from Guerrilla Warfare, was the change from pragmatism, where Guevara emphasised that 'new experiences can vary and improve these concepts [and] we offer an outline not a bible', to strict adherence to the foco theory. ${ }^{97}$ Guevara's increasing theoretical rigidity is clearly spelled out in the prologue he wrote to Vo Nguyen Giap's, People's War, People's Army. ${ }^{98}$ Che completely neglects the absolute primacy Giap gave to the political struggle and selectively interprets the work to enable himself to draw remarkable similarities to his own writings. Guevara even went as far to claim that in Vietnam the liberation struggle began with a mobile guerrilla foco. ${ }^{99}$ Ramm bluntly criticises Che's selective interpretation of Giap's' writing: 'Here we have a perfect example of how Guevara deals with his fundamental differences with the Marxist-Leninist tradition - he pretends they do not exist.... In short, Guevara's propositions ... are based on a highly dubious reading of Giap. ${ }^{100}$

Added to this increasingly Marxist environment was the arrival of Régis Debray, a young French intellectual recently graduated from the Ecole Normale where he studied under the renowned Marxist scholar Louis Althusser. ${ }^{101}$ Debray travelled to Cuba in 1959, and then returned in 196 I to fulfill the role of revolutionary ambassador: "At their [Cuban authorities'] invitation Debray became the only man to have personally witnessed the travail of the revolutionary movement in every major Latin American republic in a series of visits from 1961 to $1967 .{ }^{102}$ Between 1963 and 1964, Debray travelled to every country of South America except Paraguay, where he had intimate contact with numerous guerrilla

96 In a CBS interview in December 1964 Guevara stated: 'In America, the road to the liberation of the peoples, which will be the road to socialism, will be opened by armed struggle in nearly all countries.' Quoted in Lowy, Marxism of Che Guevara, p. 86.

97 Guevara, Guerrilla Warfare, p. 132.

98 Reprinted in Bonachea and Valdés, Che, 'People's War, People's Army', pp. 149-54.

99 According to Ramm, in 'Vietnam the guerrillas were local tactical forces, not mobile and strategic. Giap contrasted guerrilla warfare with mobile warfare; the later follows the former.' Marxism of Régis Debray, p. 208, fn. 37. $\quad{ }^{100}$ Ibid., pp. 83-4.

101 Ibid., p. I.

102 Robin Blackburn, 'Introduction' to Régis Debray, Strategy for Revolution (New York, I97I), p. 7 . 
movements. Debray's well-developed Leninist background served to complement and theorise Guevara's anarchistic Marxism. ${ }^{103}$

After Debray's guerrilla tour of 1963 and 1964, he wrote two essays which retold his experiences. ${ }^{104}$ Debray took Guevara's notion of a vanguard foco, in place of the vanguard party, one step further.

The presence of a vanguard party is not... an indispensable pre-condition for the launching of an armed struggle... it is possible to do without a vanguard Marxist-Leninist party of the working class.... An anti-imperialist national liberation struggle in a colonial or semi-colonial territory cannot be conducted under the banner of Marxism-Leninism or the leadership of the working class for obvious reasons: de facto 'aristocratization' of the relatively small working class, the nationalist character of the anti-imperialist struggle. As for the party, that will be formed and its cadres will be selected through the natural process of the liberation struggle, as happened in Cuba. ${ }^{105}$

Debray's wholesale dismissal of the working class '[f]rom the standpoint of traditional Marxism-Leninism, is a major, if not the greatest, heresy' ${ }^{106}$ The main point Debray makes is that a vanguard party is unnecessary because the role of such a party is undermined by the guerrilla army which must be primary in the Latin American revolution.

Of all the countries Debray visited, he was most thoroughly informed on the events in Venezuela. In 1963 , the Venezuelan Communist Party (PCV) adopted the armed struggle and received praise from Castro for doing so. Nonetheless, throughout 1964 a division emerged between the PCV and its armed wing, the Armed Forces of National Liberation (FALN) over strategy. Douglas Bravo, the leader of the FALN, cited the writings of Havana to justify his claims for the necessity of the sierra to be independent of llano directives in pursuing the armed struggle. The PCV, however, desired to keep the FALN subordinate to their directions. The rift between the Venezuelan left over strategy served to weaken and divide it. Debray decided that a vanguard party would not be necessary during the initial stage of the struggle because it would, in fact, present more problems than advances. Thus, what Debray calls 'Castroism' (which is Guevara's foco theory) is Leninism adapted to Latin American conditions. Debray's 'Castroism' and Guevara's foco theory has the sierra

103 Ramm, perhaps, states this point too strongly: 'Guevara's acquaintance with Leninist thought was scanty, ... the burden of the theoretical struggle passed to the brilliant, young, French intellectual, Régis Debray.' Marxism of Régis Debray, p. viii. Ramm's overall thesis is that Debray 'Leninized Guevara'.

104 The first was a lengthy essay published in January 1965, 'Castroism: The Long March in Latin America', and the second was published in March of the same year 'Problems of Revolutionary Strategy in Latin America'. Both essays are reprinted in Régis Debray, Strategy for Revolution.

105 Debray, 'Castroism: The Long March in Latin America', p. 53.

106 Ramm, Marxism of Régis Debray, p. 29. 
serve as the surrogate for the Leninist vanguard party in the struggle, but they do not adequately address the necessity for politicising the masses in conjunction with the armed struggle; they regard the process as one and the same.

In I 966 Debray combined his earlier essays into a book, Revolution in the Revolution?, published in Havana in January $1967 .{ }^{107}$ Debray takes the vanguard foco to the next logical step by eliminating the party altogether and infusing it into the foco:

under certain conditions, the political and military are not separate, but form one organic whole, consisting of the people's army, whose nucleus is the guerrilla army. The vanguard party can exist in the form of the guerrilla foco itself. The guerrilla force is the party in embryo. [emphasis in original] ${ }^{108}$

He then goes on to comment on the numerous logistical problems an urban support network presents, such as unity of command and sectarianism. Further, Debray claims any ties to the city serve to weaken the armed struggle because the city is where the dictatorship is strongest and the insurgency most vulnerable. Debray quotes Castro: 'The city is the cemetery of the Revolutionaries and resources' and then goes on to add himself, "the police and their North American advisers wait on their home ground until the guerrilla leaders come to the city'. ${ }^{109}$ For Debray, the 'weakest link' of the foco lies in the llano, and conversely, the 'weakest link' of the dictatorship is found in the sierra. As a result, all political and military activity should be concentrated in the mountains. The most effective method to counter the inherent weaknesses of the llano is to divorce it altogether from the armed struggle, postponing the formation of a party until later: 'The people's army will be the nucleus of the party, not vice versa. The guerrilla forces is the political vanguard in nuce and from its development a real party can arise' [emphasis in original]. ${ }^{\mathbf{1 1 0}}$ Debray's representation of the foco is the most extreme example of the 'sierraisation'

${ }^{107}$ Régis Debray, Revolution in the Revolution?: Armed Struggle and Political Struggle in Latin America (New York, 1967). Following Che's death many blamed Debray for severely distorting the foco theory. These claims are unfounded for several reasons: first, 'Debray had a number of long conversations with Castro and members of Castro's inner circle who made available to him numerous unpublished documents, including military correspondence'; second, according to Roberto Fernández Retamar, editor of Casa de la Américas, 'no one else had access to such a wealth of materials for historical research'; and third, the very fact that it was published by Casa de las Américas and the first printing entailed more than 200,000 copies for a mass audience indicates Debray's work had the backing of the Cuban government. Ramm, Marxism of Régis Debray, p. 61; and the introduction by Huberman and Sweezy to Revolution in the Revolution, p. 7.

${ }^{108}$ Debray, Revolution in the Revolution?, p. 106.

109 Ibid., p. 69. 110 Ibid., p. 116. 
of the foco where the llano plays no role at all. The theoretical conclusions of Debray are so far removed from the Cuban Revolution that they no longer fundamentally resemble the Cuban experience.

\section{'Internationalisation' of the Foco, 1965-7}

The last categorisation of the foco, clearly evident before 1965 , is its 'internationalisation'. The years $1965-7$ distinguish the 'internationalisation' of the foco from previous years as the foco theory becomes institutionalised in several Cuban foreign policy organisations of international revolutionary support. Also, it coincides with Guevara's personal efforts at internationalising the foco with his trips to the former Belgian Congo, and his death in Bolivia. No fundamental changes occur in the foco theory, it simply takes on a worldwide audience as Guevara attempted to turn the Andean Cordillera into the Sierra Maestra of Cuba.

In February 1965, Guevara spoke at the Second Economic Seminar of Afro-Asian solidarity in Algiers, where his ideas took on a truly international perspective. ${ }^{111}$ 'There are no frontiers in this struggle to the death. We cannot remain indifferent in the face of what occurs in any part of the world. ${ }^{112}$ Geographical borders no longer represent any barriers in the armed struggle nor should individuals be limited solely to the struggle in their own country.

The theme of the speech was not confined to international revolutionary solidarity, but also represented Third World nationalism. Cuba criticised the Soviet Union for inadequately supporting Vietnam and pursuing economic policies in underdeveloped countries that did not represent authentic communist ethics. ${ }^{113}$ Guevara called for the advanced socialist nations to invest their capital in underdeveloped countries committed to building socialism: 'The development of the underdeveloped countries must be underwritten by the socialist countries. ${ }^{114}$ Che echoed his earlier speech delivered in 1964 to the United Nations General Assembly where he criticised the Soviet Union for pursuing imperialistic policies and détente. ${ }^{115}$ Basically, he called on the Soviet Union as the vanguard of the socialist world to fulfil its role as leader. Without the appropriate assistance of the Soviet Union in the Third World, Cuba would fill the leadership void by becoming the representative of Third World interests and revolution. Guevara hinted at the need for forming an organisation,

111 The speech is reprinted in Bonachea and Valdés, Che, 'Revolution and Underdevelopment', pp. 350-9.

112 Ibid., p. 350.

113 See Guevara's speech given in 1963 on 'Solidarity with Vietnam' for earlier remarks on the same topic. Reprinted in Gerassi, Venceremos!, Pp. 286-9I.

114 Guevara, 'Revolution and Underdevelopment', p. 353.

115 See his UN speech reprinted in Bonachea and Valdés, Che, 'Colonialism is Doomed', pp. 334-49. 
similar to Afro-Asian solidarity, which would include the countries of all three underdeveloped areas: Latin America, Africa, and Asia.

In January i 966, Guevara's proposal was adopted at the Tricontinental Conference in Havana where the Organisation for Solidarity with the Peoples of Africa, Asia, and Latin America (OSPAAL) was founded. ${ }^{116}$ The I 2-member secretariat of OSPAAL included representatives from Syria, Guinea, North Korea, Venezuela, Pakistan, the Congo and other countries and colonies. The Latin American delegates to the conference, in addition, founded the Organisation for Latin American Solidarity (OLAS) to deal specifically with issues pertaining to the western hemisphere. OLAS, however, had a short life. Its only conference was held in August 1967, and after Guevara's death it became absorbed by OSPAAL. ${ }^{117}$

From I965 to Guevara's death, no fundamental change occurred in the foco theory since, in fact, there was little written by him or even about him other than speculations concerning his whereabouts. In June i965, Guevara left his post as Minister of Industries and disappeared. On 3 October i 96 , Castro read Che's farewell letter which declared: 'Anywhere I am, I will feel the responsibility of being a Cuban revolutionary and as such I will act. ${ }^{118}$ What happened between his departure from Cuba and the first entry on 7 November 1966 of his Bolivian Diary remains a mystery. Most biographers of Guevara comment on his trip to the former Belgian Congo and his participation in guerrilla activities, but the details are scarce. ${ }^{119}$

The only document on guerrilla warfare authored by Guevara after his disappearance in 1965 was his 'Message to the Tricontinental' read in his absence at the OLAS meeting in August of $1967 .{ }^{120}$ The 'message' is clear; Che advocated creating numerous focos to divide the imperialist forces of the United States through a protracted struggle as occurred in Vietnam:

The Cuban Revolution has before it a task of much greater relevance: to create a second or a third Vietnam.... What a luminous, near future would be visible to us if two, three or many Vietnams appeared throughout the world with their

116 Domínguez, To Make A World Safe for Revolution, p. 270.

117 Che "was the absent inspiration of the conference. He was elected the honorary president of the organization. OLAS in fact was so closely identified with him, that it was difficult for it to survive his death.' Gott, Guerrilla Movements in Latin America, p. 35 .

118 Reprinted in Bonachea and Valdés, Che, 'Letter to Fidel Castro', p. 423.

119 Future detailed investigations of Guevara's trip to the Congo could more concretely illuminate why Che left Cuba, his return to Latin America and selection of Bolivia, his mistrust of allies he did not know well in advance, and the strategy he employed in Bolivia.

120 Reprinted in Bonachea and Valdés, Che, 'Message to the Tricontinental', pp. I $70-82$. 
share of death and immense tragedies, their every day heroism and repeated blows against imperialism, obliging it to disperse its forces under the attack and increasing hatred of all peoples of the earth. ${ }^{121}$

Guevara called for the formation of many focos because neither the Soviet Union nor China adequately assisted Vietnam which was left 'tragically alone ... by the representatives of the two greatest powers of the socialist camp'. ${ }^{122}$ According to Guevara, support included more than s simple 'wishing success to the victim of aggression, but of sharing his fate; one must accompany him to his death or victory'. ${ }^{123}$ Guevara's personal attempt to create another Vietnam resulted in the former.

With the internationalisation of the foco, the motives for armed struggle become increasingly less indigenous and directed against the entire imperialistic system led by the United States. By minimising national causes for revolution, and emphasising the universality of revolutionary conditions, armed struggle becomes increasingly favourable in every country integrated into the world capitalist system. Che selected Bolivia more for its geographical suitability in launching 'two, three, or many Vietnams', and less for indigenous reasons which are essential for a guerrilla movement to survive. Che's Bolivian Diary is a sad testament to this fact.

\section{Conclusion}

Guevara's death was a devastating blow to Cuba's foreign policy and brought about its rapid reorientation. In less than two years, Cuba reestablished state to state relations with Venezuela and Peru, whose guerrilla groups had received open support from Havana prior to Guevara's death. ${ }^{124}$ In 1970, Salvador Allende of Popular Unity was elected president of Chile and embarked on the socialist path by the ballot, not the bullet. The death of Guevara, and the apparent feasibility of the peaceful road to socialism, resulted in an almost wholesale abandonment of the foco theory for the pursuit of other tactics and strategies.

The theoretical distance travelled by the foco theory from the Cuban Revolution to Guevara's death in Bolivia reflects a considerable distortion of the Cuban experience. In 1960, when Guerrilla Warfare was published, the important role of the llano was not accounted for. From i 960 to 1962 , the sierra's importance in the revolution took on an elevated, ahistorical proportion. From 1963 to 1965 , as the foco theory became 'Marxianised',

121 Ibid., p. I 82.
124 Ibid., pp. $172^{-3}$.
According to Domínguez's Bargaining Rule: 'Support for revolution could be used for bargaining. Cuba would suspend its ongoing support for revolutionary movements... in return for a suspension of hostilities against Cuba and other benefits.' Domínguez, To Make a World Safe for Revolution, p. I 20. Once Cuba gave up 'exporting revolution' they rapidly became integrated into hemispheric politics. 
it excluded reformist bourgeois members of the population. By declaring the socialist nature of the armed struggle, it also attracted the close attention of both the highly anti-communist national armies and the United States. The 'internationalisation' of the foco resulted in international reasons for revolution superseding indigenous causes. The entire period from i 960 to 1967 witnessed a fundamental shift away from the Cuban experience, and, as a result, the Cuban experience became unrepeatable.

After Debray's release from prison and a trip to Allende's Chile, he began a major revision of his writings on guerrilla warfare. In an essay entitled 'Time and Politics', Debray disavowed Guevara's second lesson of the Cuban Revolution that the conditions for a revolutionary situation can be created by the foco. 'It is impossible to provoke or improvise crisis situations artificially; every country, every locality, has its own special historical time, its own pace, its speed of development. ${ }^{125}$ Also, Debray emphasised the need for a 'thorough nation-by-nation class analysis' to take account of the 'historical, social, and economic' peculiarities of each country to determine the appropriate strategy. Debray commended the Chilean Revolution and advocated pursuing socialism through the political struggle if possible. ${ }^{\mathbf{1 2 6}}$ Debray's writing after 1967 accurately point out that the Cuban Revolution had been misinterpreted in the literature on guerrilla warfare, which, in part, accounts for the failure of every armed group that adopted the foco theory.

Nicaragua appears to be the only country where the foco theory was proved valid. FSLN strategy, however, underwent several fundamental changes which brought the Nicaraguan strategy closer to the actual Cuban Revolution - in contrast to the foco theory. In 1963, an FSLN foco was found operating on the Honduran border ready to invade Nicaragua, and, thus, begin the revolution. But the foco did not have popular support and was quickly defeated. In 1967 , another foco had formed around Matagalpa, but it too was rapidly defeated. The defeat of the second foco and the death of Che Guevara in the same year began a process whereby the FSLN changed its strategy. Over the next i 2 years the FSLN adopted a protracted war strategy, created a strong llano wing of the FSLN to politicise the masses, and even formed an alliance with the national bourgeoisie. This broad base of support, as in the Cuban Revolution, integrated the armed struggle of the countryside into the political struggle of the cities. Loveman and Davies succinctly summarise the changes made by the FSLN to Guevara's foco theory:

If the Sandinistas inherited Che Guevara's most important legacy - the inspiration 125 Régis Debray, Prison Writings, 'Time and Politics' (New York, 1973), p. I 30.

126 Régis Debray, The Chilean Revolution: Conversations with Allende (New York, 1971). 


\section{Matt D. Childs}

to challenge the dictatorship through armed struggle - they were also forced to modify profoundly the tactical, strategic, and political implications of foquisimo in order to prevail.

First, only armed struggle proved sufficient to overthrow Somoza,... but only protracted warfare combined with years of political organization and mobilization brought the foco's aspirations to fruition. Second, this mobilization required the incorporation of significant numbers of entrepreneurs, clerics, workers, and traditional political elites to oust the dictator. Third, even this political-military alliance would likely have failed without extensive assistance from foreign nations.... Finally, as in Cuba, the withdrawal of U.S. support from the Nicaraguan dictatorship allowed domestic civil opposition to coalesce around the less numerous FSLN cadres and defeat Somoza. ${ }^{127}$

Thus, moving beyond a foquista analysis, the Nicaraguan Revolution demonstrates remarkable similarities with the actual Cuban Revolution. It was not until the FSLN challenged the foco theory that they had any success in the revolutionary struggle. When they finally developed a strategy resembling the actual Cuban Revolution, Somoza seemed to fall as rapidly and mysteriously as Batista. In the end, then, the triumph of the Nicaraguan Revolution through its changes in the foco theory points out the fundamental error's of Guevara's strategy.

In summary, a close examination of the emergence and evolution of the foco theory juxtaposed to Cuban politics demonstrates it was not formulated in a theoretical vacuum. Rather, there existed an apparent discourse between Cuban politics and the evolution of the foco theory. Changes made to the theory served to strengthen the veterans of the sierra vis-à-vis the llano, i.e. 'old Communists', during the first years of the revolutionary government. Since the foco theory gave considerable weight to subjective conditions and the sierra in the armed struggle, it served to legitimise the fidelista centrality in the Cuban political apparatus. The broad changes made to the foco theory, which $I$ have categorised as 'sierraisation I 960-2', 'Marxianisation i 962-5', and 'internationalisation 1965-7', reflect the main thrust of Cuban politics and its leaders during these years. Indeed, the above labels could easily be applied to the economic, social and political policies of the ig6os as well. After all, policy, theory and the like are constructed at a specific time for a specific reason-illuminating current political realities and the partiality of the authors. Examining the emergence of ideas, programmes and actions in a discourse manner, unearths a wealth of historical information buried just below the surface.

127 Loveman and Davies, 'Nicaragua', pp. 383-4. 